\title{
TKA で良好な可動域を獲得するには
}

\author{
[How to Achieve Good ROM after CR-TKA]
}

中根邦雄 ${ }^{*}$ Kunio Nakane

総合大雄会病院人工関節センター

Key words：TKA／ROM／手術手技/リハビリテーション

\section{はじめに}

人工膝関節置換術 (total knee arthroplasty: TKA）の目的は, 障害膝の除痛, 支持性, 可動域 (range of motion : ROM), 耐久性の獲得を求め, 患者にとってょり適した ADL と QOL を再現する ことである.

TKA には, 後十字勒帯 (posterior cruciate ligament : PCL) を温存する CR (cruciate retention) 型と PCL を切除して脛骨上の post と大腿骨の cam により PCL 機能を代償させる PS（posterior stabilizer) 型が主に使用されている。近年, 前十 字勒帯 (anterior cruciate ligament：ACL) と PCL の両勒帯を温存する BCR (bi cruciate retaining) 型が使用され始めたが，まだ安定した成績が出て いない，現在では，軟部組織バランスを獲得する ためには PS 型のほうがやさしいとする観点から PS 型が多く使用されている。 それに対し， CR 型 は正常膝の形態と勒帯バランスを再現する必要が あり手技的に難しいとされているが, PCL を温存 することで, より高い安定性と脱臼の心配もなく正 座が可能となることから, 徐々に増えつつある.

筆者らは TKA に際し, 日本人の日常生活に適 した膝関節の ROM と安定性を得るため, 後十字

* 総合大雄会病院人工関節センター

( ₹491-8551 愛知県一宮市兴 1-9-9)

E-mail : seikei@daiyukai.or.jp

DOI : 10.2490/jjrmc.55.1017
勒带温存型人工膝関節置換術（CR 型 TKA）を 行っている1,2).

手術では, 大腿骨遠位の切除は, 大腿骨コンポー ネントのメタルの厚さとする “独自の表面置換法” で行っている. また, 大腿骨コンポーネントの設置 は, 日本人の大腿骨遠位の形態（前弯）を理解し， その膝の本来の位置に設置すべく, 仮の joint line を大腿骨遠位の intercondylar notch point（顆間 部) と規定 ${ }^{3-5)}$, 大腿骨遠位を軽度屈曲位 $\left(7 \sim 8^{\circ}\right)$ に切除して，その膝の本来の位置に設置する.

勒帯バランスは, 膝の安定性を得るため軟部組 織の剥離は最少とし, ACL は切除するが, PCLは 温存し, 内側側副勒帯 (medial collateral ligament : MCL), 外側側副勒帯 (lateral collateral ligament : LCL) の解剖学的勒帯バランスの維持 に努める.

筆者らの手術手技とリハビリテーションで, $150^{\circ}$ 以上の正座膝が約 $10 \%$ 得られ，4種類の人工膝関 節機種 (CR 型) で正座が可能であった（図 1).

CR 型 TKA 術後の良好な ROM と安定性は患 者にとってよりよい ADLをもたらし, 正座, スポー ツも可能となる（図 2).

\section{CR 型 TKA の考え方}

\section{1。日本人の大腿骨の前弯を考慮}

大腿骨コンポーネントの設置位置は, CR 型 TKA では ROM 獲得に重要な要因と考えている. 大腿骨コンポーネントをオリジナルな位置に設置 
FINE Knee (CR)
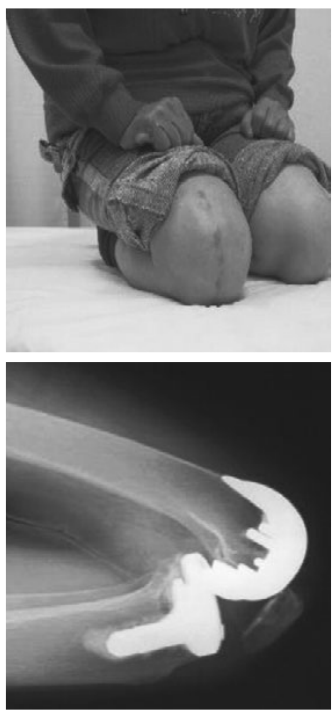

図 1 正座膝
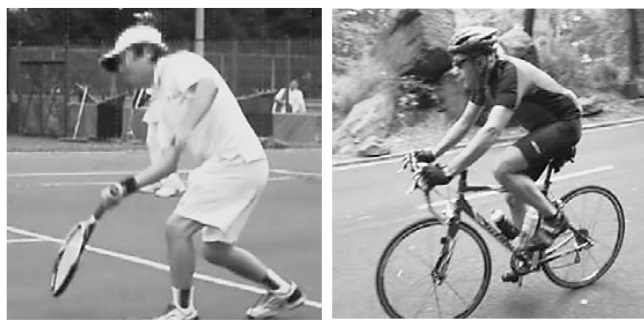

図 2 TKA 術後のスポーツ

TKA 術後の良好な ROM と安定性は患者にとってよりよ いADLをもたらし，正座，スポーツも可能となる。

するには，日本人の大腿骨の形状を理解する必要 がある．欧米人の大腿骨遠位がストレートである のに対し, 日本人高齢者の大腿骨遠位は, 平均 $7.5^{\circ}$ ほど屈曲位で前弯がみられる6)。TKA ではこの前 弯を考慮して大腿骨コンポーネントをオリジナルな 軽度屈曲位に設置する（図 3).

筆者らは日本人と中国人（吉林省）の大腿骨の 前弯について調査した。Anatomical axis と Blumensaat's line の遠位点との距離では, 日本人が平 均 $10.0 \mathrm{~mm}$ に対し, 中国人は $6.6 \mathrm{~mm}$ であり, 日本 人は大腿骨前弯が中国人より大きく，民族間に生 活習慣による差があることがみられた（図 4).
Triathlon (CR)
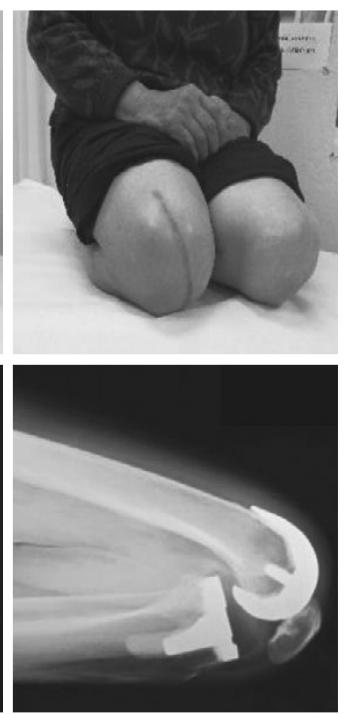

Vanguard (CR)
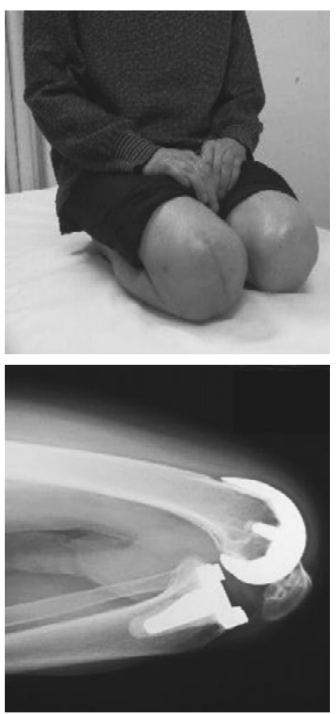

2. 大腿骨コンポーネントの 設置角と $\mathrm{ROM}$

大腿骨コンポーネントの設置角と術後の屈曲角 について検討した，筆者らの研究では， $120^{\circ}$ 以下 の屈曲不良群のコンポーネントの設置角が $7.0^{\circ}$ と やや伸展位に設置されていた。 それに対し，145 以上の深屈曲群は $7.7^{\circ}$ と, ほぼオリジナルな屈曲 位に設置されていたが有意差は認められなかった (図 5).

\section{Posterior condylar offset (PCO) 差と ROM}

PCO は膝関節の屈曲回転軸として重要であ $3^{7)}$.

非手術側（反対側）の $\mathrm{PCO}=\mathrm{A}$ と術側 $\mathrm{PCO}=\mathrm{B}$ との差で術後の屈曲角を検討した．X 線写真は左 右膝とも同じ条件で撮影した， $120^{\circ}$ 以下の屈曲不 良群の PCO 差が $1.46 \mathrm{~mm}$ であるのに対し， $145^{\circ}$ 以上の深屈曲群の $\mathrm{PCO}$ 差は $0.58 \mathrm{~mm}$ と少なかっ た。この事実から PCO 差の少ないジャストサイズ の群に深屈曲が得られていたが, 症例数が少ない 
ためか，有意差は認められなかった（図 6).

\section{TKA の術後 ROM 獲得の要因}

TKA 術後の ROM の獲得要因として, 1999 年 に丹羽は次のように述べている8).

1. 術前の $\mathrm{ROM}$

\section{欧米人日本人の大腿骨前弯を考慮}

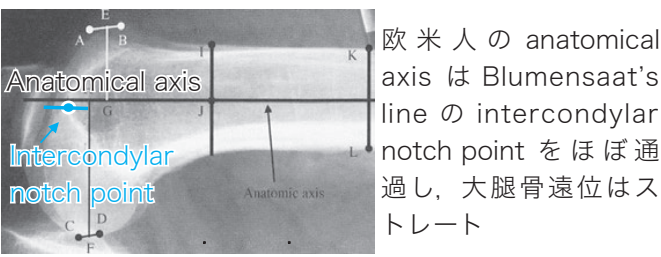

日本人
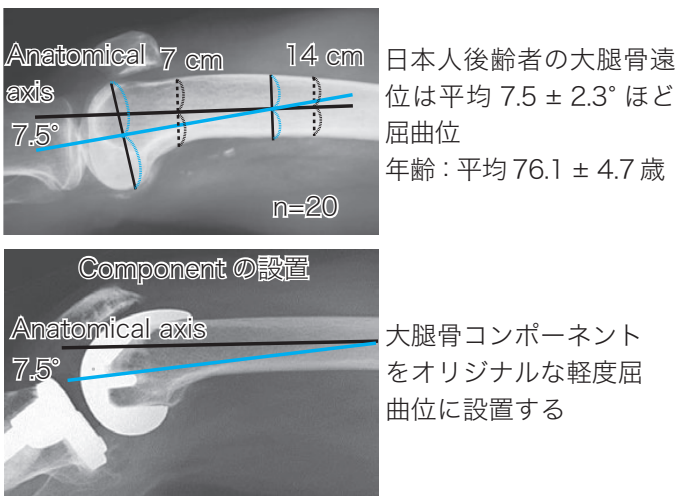

大腿骨コンポーネント をオリジナルな軽度屈 曲位に設置する

図 3 大腿骨の前弯

\section{2. 手術手技}

3. 人工関節のデザイン

4. 後療法

筆者らはこれらに加え筋肉, 軟部組織の柔軟性 も $\mathrm{ROM}$ 獲得の要因ではと考えている.

\section{1. 術前の ROM}

2012 年 1 月〜 2015 年 12 月の期間で，同一手技 で, 当院で手術し半年以上経過した FINE Knee （CR）で, 内反型変形性膝関節症（OA） 401 膝と 関節リウマチ（RA） 3 膝の計 404 膝の術前後の $\mathrm{ROM}$ をみてみる。 404 膝の平均年齢は 73.6 歳, 男 性 55 例 71 膝, 女性 232 例 333 膝である. 術前平 均 ROM は $-5.1( \pm 6.7)^{\circ} \sim 132.2( \pm 15.8)^{\circ}$, 術前 $100^{\circ}$ 以下の屈曲不良膝は 20 膝（5\%）であった. 術後の平均 $\mathrm{ROM}$ は $-1.3( \pm 2.9)^{\circ} \sim 135.4( \pm 2.9)^{\circ}$ と, 術前よりわずかに改善した. 膝屈曲角は膝抱 えで計測した。

術前 $100^{\circ}$ 以下の屈曲不良膝の術前後の $\mathrm{ROM}$ では, 術前の平均 ROM は-15.5 $( \pm 13.7)^{\circ} \sim 81.8$ $( \pm 19.2)^{\circ}$ で, 術後の平均 ROM は $-2.6( \pm 4.7)^{\circ}$ 〜 122.0（ \pm 9.5$)^{\circ}$ と予想以上に改善した. 術前よ
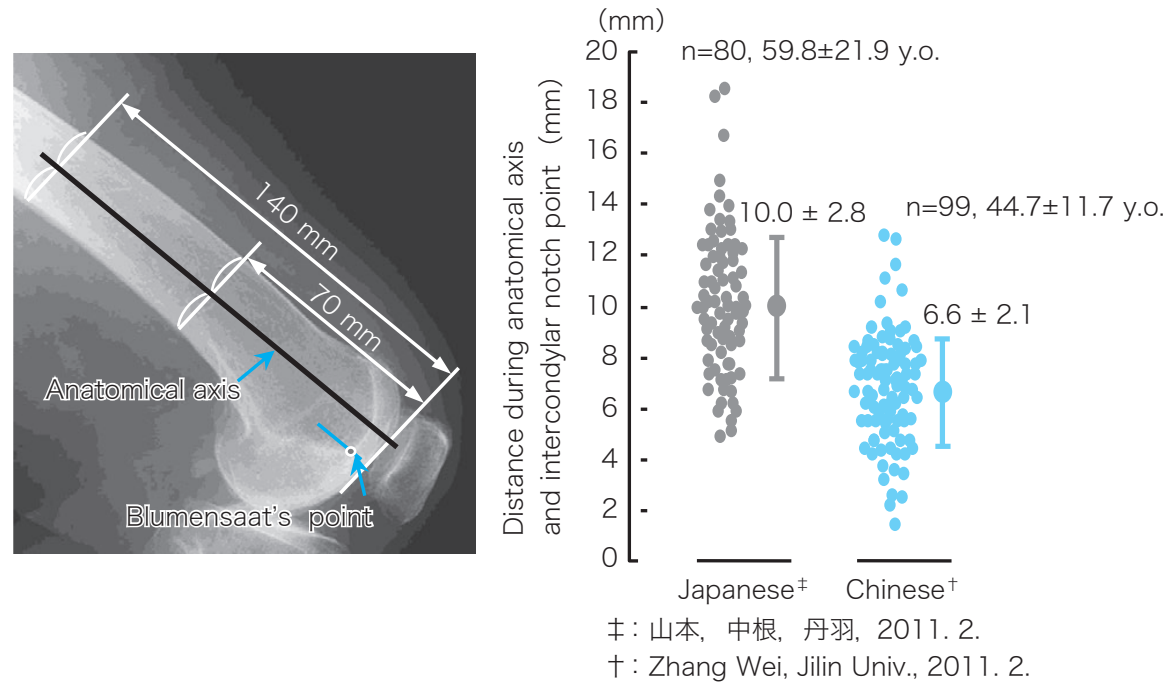

図 4 大腿骨前弯の比較（日本人/中国人）

Jpn J Rehabil Med Vol. 55 No. 1220181019 

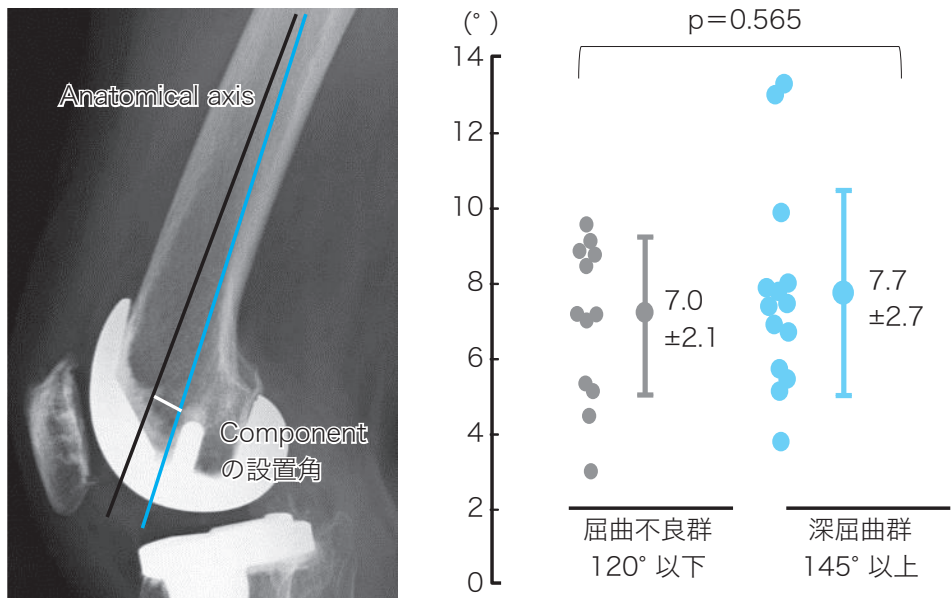

図 5 大腿骨コンポーネントの設置角とROM（文献 2 より引用）

コンポーネントは屈曲気味設置のほうがよく曲がる.
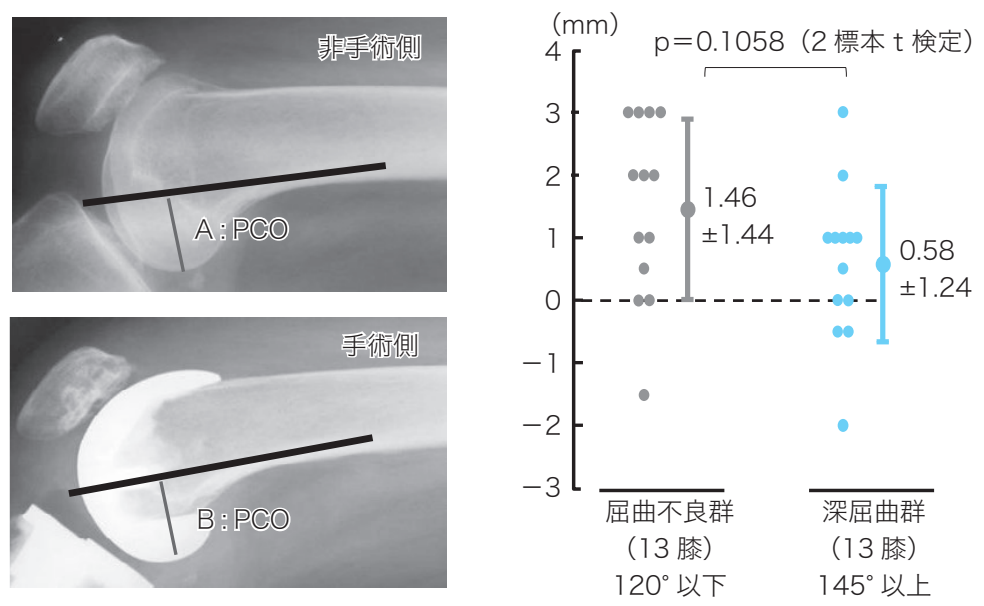

図 6 Posterior condylar offset (PCO) 差と ROM (第 42 回日本人工関節学会)

非手術側と術側と比較した PCO 差 (A-B). PCO 差の少ない群に深屈曲が得られている。

り術後膝屈曲角が悪化した症例は 1 例もなかった. また，全症例中 41 膝（10.1\%）に術後正座膝を認 めた．正座膝の術前後の最大屈曲角は平均 142.3 $( \pm 8.3)^{\circ}$ から術後は $149.8( \pm 1.1)^{\circ}$ に改善した. 術後の正座膝群では, 術前 $120^{\circ}$ 以下および $20^{\circ}$ 以上の伸展障害の膝はなく，術前の ROM はす心゙ て良好であった ${ }^{9)}$ (図 7).

\section{2. 手術手技（表面置換術）}

手術は，この数年間の臨床経験から欧米人のス トレートな大腿骨と異なる日本人高齢者の大腿骨 の生理的前弯を考慮し，大腿骨遠位の intercondylar notch point（顆間部）を仮の joint line とし, 破壊された膝関節の軟骨および骨を切除し，大腿 骨コンポーネントを患者の膝の本来の位置に設置 する “独自の表面置換術法”である ${ }^{2}$ (図 8)。大腿 骨遠位は，患者のもつ滕の joint line の位置で，大 
術前屈曲不良膝（20 膝）

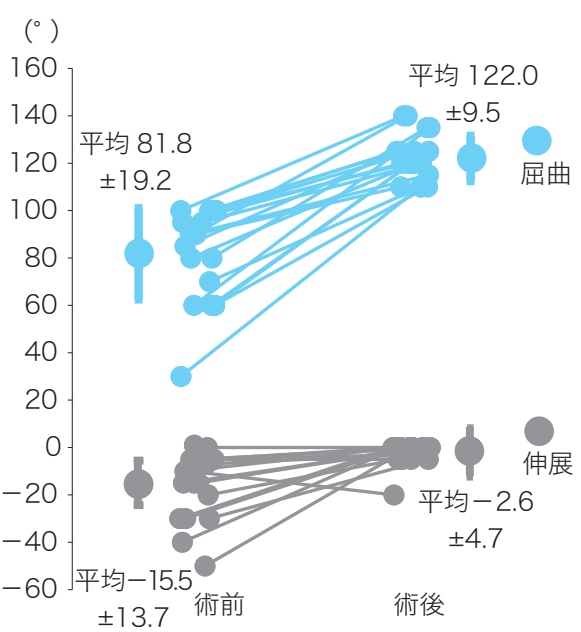

術後正座膝 (41 膝)

平均 149.8

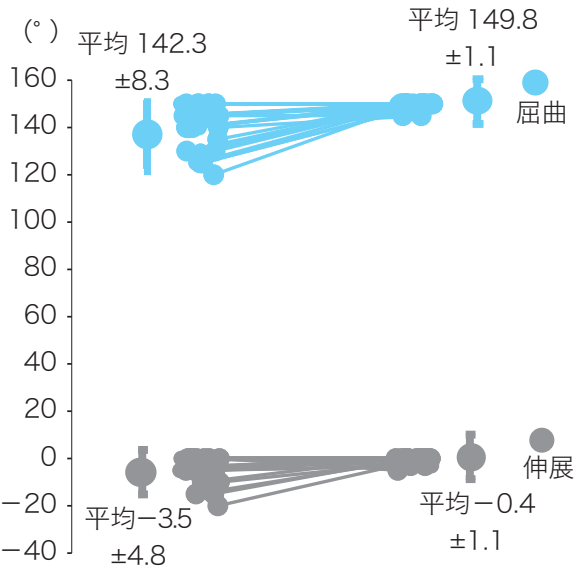

術前

術後

図 7 術前後の可動域（404 膝中）（第 47 回日本人工関節学会）
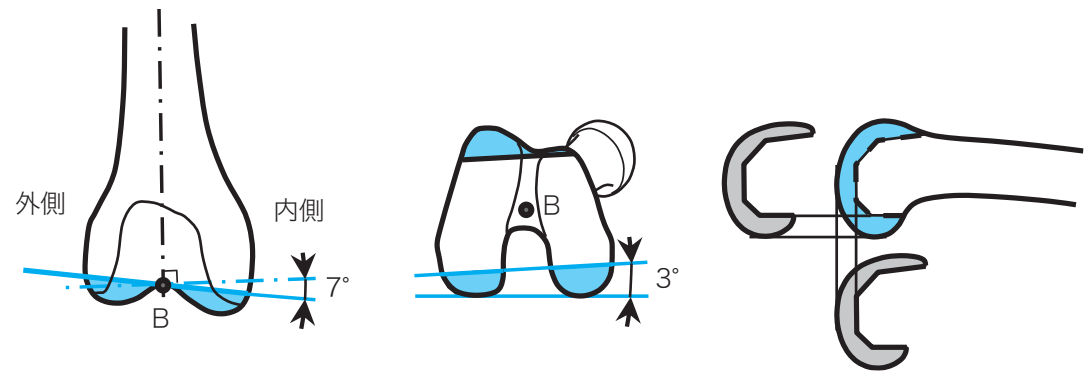

図 8 手術手技（表面置換術のコンセプト）（文献 2 より引用）

Intercondylar notch point を仮の joint line とし, 大腿骨遠位を外反 $7^{\circ}$. PCA 基準で外旋 $3^{\circ}$ で, コンポーネントの厚みを切除.

B : intercondylar notch point

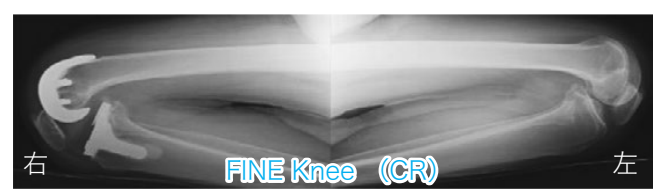

図 9 ジャストサイズに設置

日本人の大腿骨前弯を考慮し，ジャストサイズの大腿骨コ ンポーネントをオリジナルな位置（軽度屈曲位）に設置。

腿骨カッティングジグ（丹羽十手ジグ）により外反 $7^{\circ}$ に切除する. 大腿骨遠位前後面の切除は, 軟骨 の摩耗が比較的温存されている後顆軸（posterior condylar axis：PCA）を基準として，外旋 $3^{\circ}$ に大
腿骨カッティングブロックジグで大腿骨コンポーネ ントのメタルの厚み幅を切除し, PCO を術前後で 等長とする. 大腿骨コンポーネントの設置は, ジャ ストサイズのコンポーネントをオリジナルな位置に 設置する（図 9)。膝関節の機能を温存するため, 軟部組織の剥離は最小限にとどめ, PCL は脛骨部 で島状に温存し，MCLの剥離は深層のみとする. 内反滕に対する勒帯バランスは，脛骨内顆部の骨 棘および脛骨内側の骨切除 (reduction osteotomy）で対応する. 拘縮膝に対しては, 半月板の全 切除と大腿骨後顆の後方骨棘を十分に切除し, 膝 

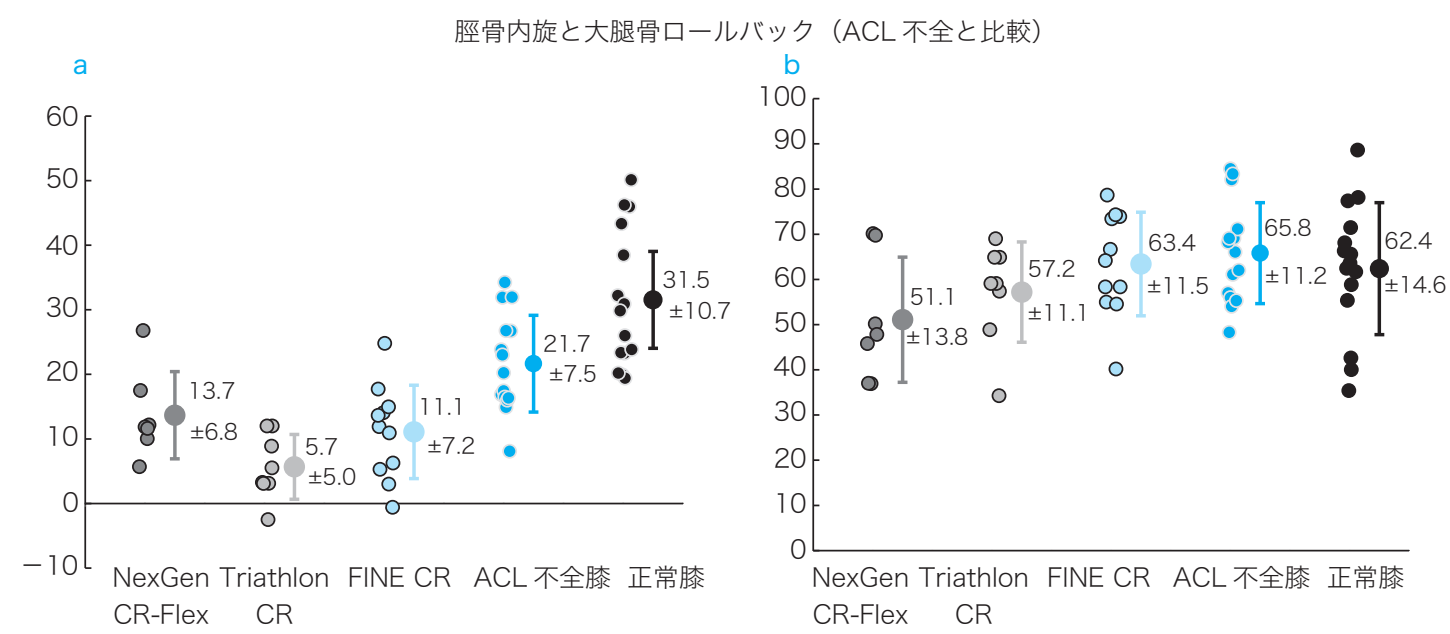

図 10 インプラント特性（正座膝）（第44 回日本人工関節学会）

a : 脛骨内旋度.

脛骨内旋度は，機種間に差があり，ACL 不全膝と差を認めた（機種間のインサートの形状特性によるか）。

$b$ : 大腿骨ロールバック率.

大腿骨ロールバックは，機種間に比較的差を認めず， ACL 不全膝に近い値であった。

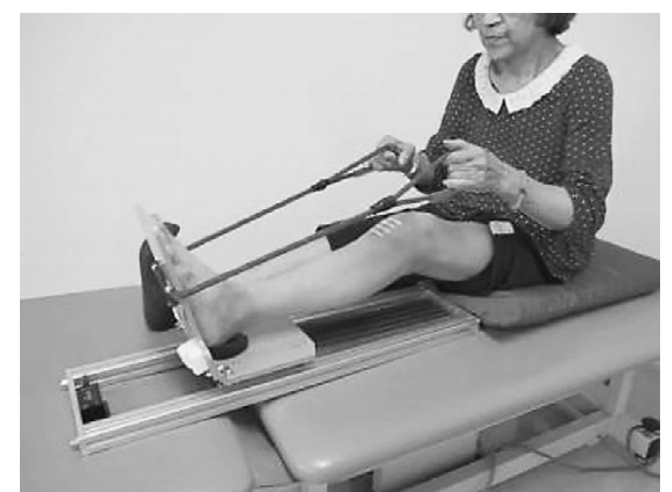

図 11 NG-ROM マシーン（特許取得）

関節後方に十分なスペースをつくる，手術には独 自の手術器具を使用し, 人工膝関節コンポーネン 卜 (大腿骨, 脛骨, 膝蓋骨) はすべてセメント固定と する. 全例膝蓋骨の置換と lateral release を行う.

\section{3. 人工関節のデザイン}

筆者は 1988 年に丹羽らが開発した SEAP (CR) : 19 膝を使用して以来, Whiteside $(\mathrm{CR}): 10$ 膝, Omnifit (CR) : 9 膝, Duracon (CR) : 440 膝, NexGenCR-Flex : 472 滕, FINE Knee (CR) : 740
膝, Vanguard (CR) : 27 膝, Triathlon $(\mathrm{CR}): 30$ 膝, Evolution (CR) : 28 膝, Persona $(\mathrm{CR}): 27$ 膝 などの $\mathrm{CR}$ 型人工膝関節を 2,000 滕ほど同一術式 で行ってきた。これらの機種の中で, 日本人の骨 モデルを参考につくられた国産人工膝関節 FINE Knee（CR）は日本人の膝の形態によく適合し，良 好な術後の膝 $\mathrm{ROM}$ が得られた。

\section{術後正座膝のインプラント間の特性について}

膝関節の屈曲には, 脛骨の内旋と大腿骨のロー ルバックが伴うことが知られている ${ }^{10,11)}$. 筆者ら が ACL 不全膝と比較したデータでは, 脛骨内旋度 は, NexGenCR-Flex 13.7 , Triathlon (CR) 5.7 , FINE Knee (CR) 11.1と機種間に差を認め, $\mathrm{ACL}$ 不全膝 $21.7^{\circ}$ とも差を認めた．このことは, 機種間でのインサートの形状特性によると考えら れる。一方, 大腿骨ロールバック率では, NexGen CR-Flex 51.1\%, Triathlon (CR) 57.2\%, FINE Knee（CR）63.4\% と機種間にあまり差を認めず, ACL 不全膝の $65.8 \%$ に近い值を示した ${ }^{12)}$ (図 10). この事実より，CR 型 TKA の屈曲には，脛骨の内 


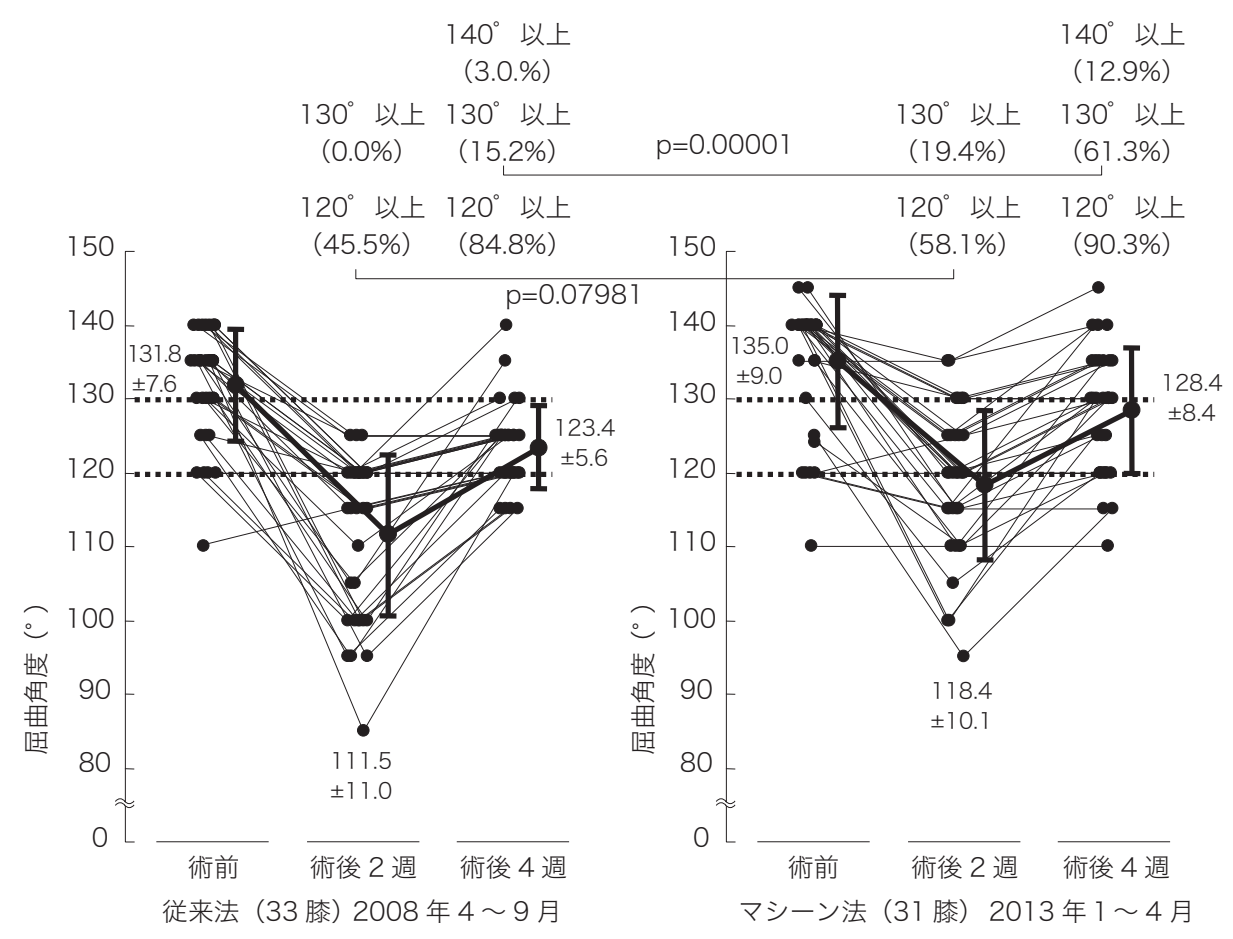

図 12 術後のリハビリテーションの比較（文献 13 より）

旋より大腿骨のロールバックが重要と考える.

\section{4. 後療法（リハビリテーション療法）}

TKA で良好な ROM を獲得するには, 手術手技 に次いで術後のリハビリテーション療法が重要で ある、それにもかかわらず，整形外科医は TKA 術後にあまり興味をもたず，各施設の理学療法士 (PT)，作業療法士（OT）任せである. 当院では, 術後の ROM 訓練に際し CPM (continuous passive motion）マシーンを使用せず，筆者らが特許 取得した手動式の NG-ROM マシーン（non gravity-range of motion machine）を使用している (図 11)。このマシーンは, 踵を台座に置くことに より，下肢を無重力状態にし，筋活動をゼロにし， さらに手紐を引っ張ることにより足関節が背屈位 になり, ハムストリングの緊張を高め, 膝の屈曲を アシストできることが特徵である。 また，この NGROM マシーンは CPM マシーンと違って疼痛コン
トロールが自分でできるため, 楽しんで ROM 訓練 ができることも特徵である. 従来法の徒手矯正法 と, NG-ROM マシーンを使用したリハビリテーショ ンの比較では, 術後 2 週目の $120^{\circ}$ 滕屈曲獲得率 では, 従来法が $45.5 \%$ に対し, NG-ROM マシーン 法は $58.1 \%$ で有意差は認められなかったが, 術後 4 週目の $130^{\circ}$ 膝屈曲獲得率では従来法が $15.2 \%$ に 対し, NG-ROM マシーン法は $61.3 \%$ で明らかに有 意差を認めた（図 12）。この NG-ROM マシーンの 使用で, 術後の ROM は約 $20 \%$ の改善が得られ た $^{13)}$.

\section{当院のリハビリテーション療法について}

術後のリハビリテーション療法では下肢の腫れ をつくらないことが最も重要であり, 術直後からの 起立歩行は行っていない. 当院では術後大腿部か ら足先まで dressing (压迫包帯) と術部のアイシン グ，そして膝関節内にサクションドレナージを 2 日 間行い, ベッド上安静とする.ささらに, $10 \mathrm{~cm}$ ほど 


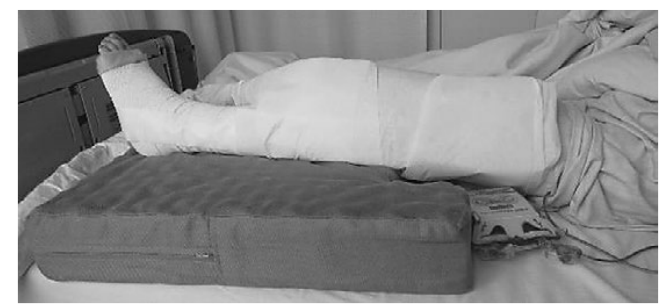

図 13 術後の安静とリハビリテーション

(1)手術肢の腫脹予防 (dressing), アイシングと患肢挙上 (2 日間安静)

(2)翌日より DVT 予防, Calf muscle setting (アクセル運動) を行う.

(3) 4 日目より本格的リハビリテーション（歩行訓練など） 開始.

のスポンジクッションで 10 日ほど下腿を挙上し, 腫れと深部静脈血栓症（DVT）予防に努める (図 13)。また,リハビリテーション療法期間中の 疼痛管理も重要で, 当院では術直前に麻酔科医に よる大腿神経ブロックと選択的腓骨神経ブロック を行い, その後, 疼痛時とリハビリテーション療法 開始前に非ステロイド性抗炎症薬 (NSAIDs) 座薬, オピオイドなどの鎮痛薬で十分に痛みをコントロー ルして ROM 訓練を行う。リハビリテーション療法 は，手術翌日よりDVT 予防のため足関節の自動 運動 (calf pumping: 当院ではアクセル運動と称す) を指導する。術後 3 日目で dressing とドレナージ などすべてをオフとし，トイレ許可とベッド上での NG-ROM マシーン訓練を開始する。術後 4 日目か ら歩行訓練などの本格的リハビリテーション療法 を開始する. NG-ROM マシーンは個人に購入して いただき（約 3 万円），ベッドサイドで 1 日，朝， 昼, 夕の 3 回, 1 回 40 50 回目安で 1 日 150 回ほ ど行う。膝屈曲角は術後 1 週目で $90^{\circ}, 2$ 週目で $120^{\circ}$ を目標に指導し, 大体 $70 \%$ の人がこの目標を クリアできる. 当院では, 関節チームの看護師が ベッドサイドで NG-ROM マシーン訓練と DVT 予 防のアクセル運動，ボールを使った大腿四頭筋の 筋トレ(相反性抑制でハムストリングのストレッチ) による膝関節伸展障害改善の指導を行う（図 14）.

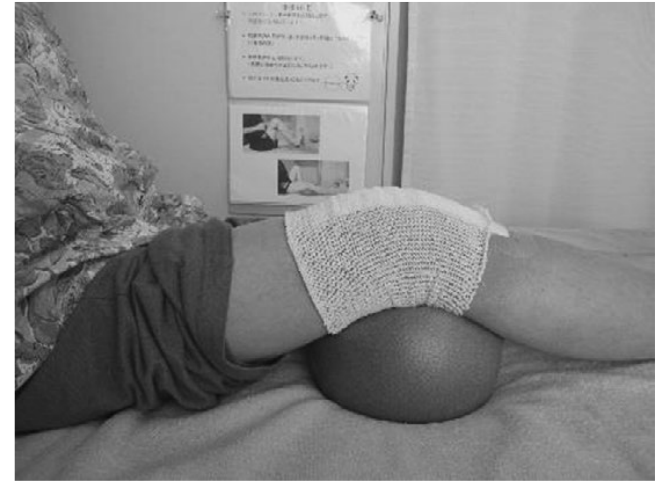

図 14 ボール訓練（大腿四頭筋の筋トレ）

もちろん筆者らも毎日 ROM, 腫れ, 感染のチェッ クを行い, 3 週目の退院時には，おおむね $130^{\circ}$ の $\mathrm{ROM}$ が得られ，ほぼゴールの状態である。 今年か ら, PTとOTチーム, 看護師チーム, われわれ医 師チームと合同で, 歩容改善の時間を設け, 正しい 歩容獲得の指導を行い, 入院中切れ目なくリハビ リテーション療法を行っている.

退院後の外来通院リハビリテーション療法は 行っていないが, 1〜2 カ月に 1 回, 外来診察時に ROM, 感染のチェックと, 曲げるためのモチベー ションを患者に指導する. NG-ROM マシーンの使 用は最低半年間行うように指導し, 外来でのフォ ローは 4 5 年間ほど行っている. 最大 ROM が得 られるのは, 術後 6 カ月〜 1 年後頃である. 中には 3 週目の退院時に正座が可能となった人が 1 人い た.

\section{CR 型 TKA で正座棣の要因}

CR 型 TKA の術後で正座膝が得られるには, 表 1 に示す要因のうち $80 \%$ ほど満たす必要がある のではと考えている. 


\section{表 $1 \mathrm{CR}$ 型 TKA で正座膝の要因}

1. Joint line を一定 (Intercondylar notch point を仮 の joint line)

2. 大腿骨コンポーネントをオリジナルな位置に設置 (軽度屈曲位)

3. ジャストサイズ（大腿骨コンポーネント）

4. 軟部組織の剥離は最小

$\mathrm{ACL}$ ，半月板は全切除，PCL，MCL，LCL は温存

5. 靯帯バランスは骨切除で行う

6. 脛骨の後傾 $\left(7 \sim 9^{\circ}\right)$

7. 関節後方のスペース（大腿骨後顆後方骨棘の全切除）

8. PF の問題 (patella tracking)

膝蓋骨の厚さ : 8 9 mm, lateral release 行う

9. GAP (屈曲 $\fallingdotseq$ 伸展)

10. 後療法 (NG-ROM マシーン)

\section{まとめ}

CR 型 TKA に際し, 良好な ROM を得るために

は. 以下がポイントになる.

・Joint line を一定にして, 脛骨の切除量で, 膝関 節の kinematics を維持する.

・オリジナルな位置に, ジャストサイズの大腿骨コ ンポーネントを設置する.

・勒帯バランスは骨切除で行い, 剥離は最少で,

PCL, MCL, LCL の生理的勒帯バランスを維持 する.

・リハビリテーション療法では患者側に深屈曲獲 得のモチベーションを与える.

・同じ術式, 術者でも術後の ROM に差があり, 術 前の ROM, 年齢, 疼痛, 筋肉, 勒帯の柔軟性な どの患者側に要因があるのではと考えている.

\section{文 献}

1) 中根邦雄, 長谷川太郎, 唐澤善幸, 藤岡克博, 寺田 聡史, 山本隆博, 丹羽滋郎: 後十字勒帯温存型人工 関節置換術の成績向上のための手術手技とその考 察. 医療法人大雄会病院誌 $2008 ; 17: 9-18$
2) 中根邦雄, 丹羽滋郎, 寺田聡史, 山本隆博: CR-TKA における勒帯バランスについて. Monthly Book Orthopaedics $2014 ; 27: 1-11$

3）寺田聡史, 中根邦雄, 余語鎭治, 小林正明, 丹羽滋 郎 : PCL 温存型人工膝関節置換術の深屈曲と joint line の関係. 日本人工関節学会誌 $2008 ; 38: 404-$ 405

4) Martin JW, Whiteside LA : The influence of joint line position on knee stability after condylar knee arthroplasty. Clin Orthop Relat Res 1990 ; 259 : 146-156

5) Cope MR, O'Brien BS, Nanu AM : The influence of the posterior cruciate ligament in the maintenance of joint line in primary total knee arthroplasty. Arthroplasty $2002 ; 17: 206-207$

6) 堀和一郎, 中根邦雄, 獅子目 亨, 山本隆博, 寺田 聡史, 丹羽滋郎：日本人の大腿骨は, 正中から前方に 弯曲している一人工膝関節（TKA）における比較. 日本人工関節学会誌 $2016 ; 46: 39-310$

7) Bellemans J, Banks S, Victor J, Vandenneucker H, Moemans A : Fluoroscopic analysis of the kinematics of deep flexion in total knee arthroplasty. Influence of posterior condylar offset. J Bone Joint Surg $2002 ; 84: 50-53$

8）丹羽滋郎：人工膝関節の ROM の改善. 骨 · 関節 · 勒帯 $1999 ； 12: 965-968$

9）中根邦雄, 寺田聡史, 大谷真史, 吉田 映, 武川竜 久, 湊しおり, 廣瀬恵介, 牧野英之, 山本隆博, 堀 和一郎：FINE Knee（CR） 404 膝の ROM を中心と した中期成績一術前屈曲不良膝と術後の正座膝. 日 本人工関節学会誌 $2017 ; 47: 7-8$

10) Walker PS, Hajek JV : The load-bearing area in the knee joint. J Biomech $1972 ; 5:$ 581-589

11) Nakagawa S, Kadoya $Y$, Todo S, Kobayashi A, Sakamoto H, Freeman MA, Yamano Y : Tibio femoral movement $3:$ full flexion in the living knee studied by MRI. J Bone Joint Surg Br $2000 ; 82$ : 1199-1200

12）中根邦雄, 丹羽滋郎, 唐津善幸, 日下部賢治, 獅子 目 亨, 吉田 映, 湊しおり, 寺田聡史, 大谷真 史, 中島 晶, 山本隆博: 表面置換術で行った CR 型 人工膝関節置換 (TKA) 術後正座膝の動態解析につ いて. 日本人工関節学会誌 $2015 ; 45: 410$

13）中根邦雄, 獅子目 亨, 丹羽滋郎, 長澤範和, 吉田 映, 日下部賢治, 中島 晶, 唐澤善幸, 石原敦司, 山本隆博 : 後十字勒帯温存型人工膝関節置換 (CRTKA）術後, 良好な ROM を獲得できる新しい機器 の (Non Gravity-Range of Motion Machine : NG$\mathrm{ROM}$ マシーン) の効果. 社会医療法人大雄会誌 $2014 ; 21: 1-8$ 